\title{
TINGKAT PENERAPAN HASIL PENDIDIKAN DAN PELATIHAN MANAJEMEN DAN KEPEMIMPINAN BP3K BAGI PIMPINAN BP3K
}

\author{
Adi Widiyanto \\ adi.widiyanto@gmail.com \\ Toni Nugraha \\ toni.nugraha@gmail.com
}

Widyaiswara pada Balai Besar Pelatihan Pertanian Binuang

\begin{abstract}
Level of Implementation of Training result of The Training BP3K Management and Leadership For BP3K Leaders. This research is an evaluation to know the level of application of training materials by training partisipants to subject matters that have been trained in Management Training and Leadership of BP3K For BP3K Leaders. This research uses descriptive method with quantitative approach and supported qualitative.Data collection by survey technique. To strengthen the results, the data were also collected from the assessment of the direct superior of the training participants and the co-workers of the training participants.

The results of this study indicate that the level of application of the material for the overall training subject matters that has been trained on average included in the category is very high. But there is material for Training Subject Matter BP3K Organizing Activity results of its application level not yet optimal, although still in high category. This is because decision-making on the aspect of organizing activities wholly depends on policies at the higher levels of Institutions.
\end{abstract}

Keywords: level of implementation, training result

\section{PENDAHULUAN}

Undang-Undang Nomor 16 Tahun 2006 tentang Sistem Penyuluhan Pertanian, Perikanan, dan Kehutanan (SP3K) Pasal 8 ayat (2) huruf d dan Pasal 15 mengamanatkan pembentukan Balai Penyuluhan di tingkat kecamatan atau Balai Penyuluhan Pertanian, Perikanan dan kehutanan (BP3K), yang memiliki peran strategis dalam menentukan keberhasilan pembangunan Pertanian. Balai Penyuluhan merupakan tempat satuan administrasi pangkal (satminkal) bagi penyuluh pertanian, perikanan, dan kehutanan yang berperan mengkoordinasikan, mensinergikan dan 
menyelaraskan kegiatan-kegiatan pembangunan pertanian, perikanan dan kehutanan di wilayah kerja balai.

Perubahan pola pikir dan perilaku pelaku utama dan pelaku usaha, persaingan pasar regional dan pasar global, fenomena perubahan iklim, kebutuhan akan kelembagaan ekonomi perdesaan yang tangguh dan mandiri serta tuntutan penyuluh yang profesional berimplikasi terhadap tuntutan pelayanan prima dalam penyediaan jasa Pendidikan melalui penyuluhan dan penyediaan informasi yang diperlukan pelaku utama dan pelaku usaha.

Dengan kelembagaan penyuluhan yang kuat di daerah maka dukungan, pengawalan, dan sinergi programprogram pembangunan pertanian, perikanan, dan kehutanan oleh pemerintah, swasta dan masyarakat diharapkan dapat dilaksanakan dengan baik.

Kelembagaan penyuluhan yang kuat ditentukan oleh kemampuannya dalam menjalankan tugas dan fungsinya secara optimal. Agar Balai Penyuluhan dapat menjalankan tugas dan fungsinya secara optimal maka dukungan sarana dan prasarana serta pembiayaan yang memadai merupakan kebutuhan yang harus dipenuhi. Namun sebaik dan selengkap apapun sarana dan prasarana yang dimiliki serta sebesar apapun pembiayaan yang diberikan, tanpa disertai kemampuan sumberdaya manusia yang mengelolanya semuanya bisa menjadi tidak berarti.

Sesuai Peraturan Menteri Pertanian

Nomor

26/Permentan/OT.140/4/2012

Tentang Pedoman Pengelolaan Balai Penyuluhan disebutkan bahwa organisasi Balai Penyuluhan terdiri dari: 1) Pimpinan Balai; 2) Urusan Ketata Usahaan; dan 3) Kelompok Jabatan Fungsional.

Oleh karena itu dalam upaya mengoptimalkan tugas dan fungsi Balai Penyuluhan di kecamatan perlu dilakukan peningkatan kompetensi pengelola balai penyuluhan tersebut. Untuk mewujudkannya Badan Penyuluhan dan Pengembangan 
SDM Pertanian melalui Balai Besar Pelatihan Pertanian Binuang telah mengadakan Pendidikan dan Pelatihan Manajemen dan Kepemimpinan bagi pimpinan BP3K.

Selanjutnya untuk mengetahui sejauhmana materi-materi yang sudah dilatihkan pada diklat tersebut telah diterapkan oleh purnawidya, maka dilakukan penelitian tingkat penerapan hasil diklat.

\section{TINJAUAN PUSTAKA}

\section{Pendidikan dan Pelatihan}

Pelatihan dan pengembangan sumberdaya manusia didefinisikan sebagai sebuah proses yang memanfaatkan berbagai metode untuk menyediakan keterampilan yang dibutuhkan, baik untuk pegawai baru maupun pegawai lama dalam melaksanakan pekerjaannya.

Secara khusus penyelenggaraan Diklat pertanian diarahkan untuk meningkatkan kinerja aparatur pertanian yang dapat menghasilkan sumberdaya manusia sehingga mampu melaksanakan tugas dan fungsi/pekerjaan secara inovatif, kreatif, professional dan berwawasan global.

Hal ini sesuai dengan Peraturan Pemerintah Nomor 101 Tahun 2000 tentang Pendidikan dan Pelatihan Jabatan Pegawai Negeri Sipil, disebutkan bahwa "Pendidikan dan pelatihan Jabatan Pegawai Negeri Sipil yang disebut Diklat adalah proses penyelenggaraan belajar mengajar dalam rangka meningkatkan kemampuan Pegawai Negeri Sipil". Pendidikan dan pelatihan kepegawaian juga merupakan bagian dari sebuah sistem pembinaan karier Pegawai Negeri Sipil yang bermakna pada pengembangan kepegawaian.

Dalam Peraturan Pemerintah Nomor 101 Tahun 2000 Tentang Pendidikan dan Pelatihan Jabatan Pegawai Negeri Sipil menyebutkan bahwa tujuan pendidikan dan pelatihan adalah:

1) Meningkatkan pengetahuan, keahlian, keterampilan,dan 
sikapuntuk dapat melaksanakan tugas jabatan secara professional dengan dilandasi kepribadian dan etika PNS sesuai dengan kebutuhan instansi.

2) Menciptakan aparatur yang mampu berperan sebagai pembaharu dan perekat persatuan dan kesatuan.

3) Memantapkan sikap dan semangat pengabdian yang berorientasi pada pelayanan, pengayoman, dan pemberdayaan masyarakat.

4) Menciptakan kesamaan visi dan dinamika pola piker dalam melaksanakan tugas pemerintahan umum dan pembangunan demi terwujudnya kepemerintahan yang baik.

\section{Evaluasi Pelatihan}

Evaluasi mengenai dampak dan efektifitas dari pelatihan diperlukan agar kelebihan dan kekurangan dalam program tersebut dapat diidentifikasi sehingga perbaikan dapat ditindak lanjuti. Hal tersebut sesuai dengan fungsi evaluasi yang dikemukakan Badu,Q., S. (2013) dalam Ramadhon (2016) yaitu untuk memperoleh informasi yang akurat dan objektif pada sebuah program, yang telah direncanakan dan diimplementasikan pada fase sebelumnya. Ulum (2015) dalam Ramadhon (2016) mendeskripsikan kegiatan evaluasi sebagai suatu tujuan yang sistematik, dan pengumpulan data secara hati-hati serta menganalisis informasi yang digunakan untuk menentukan efektivitas dan dampak dari suatu program, serta mengidentifikasi hal- hal apa saja yang harus ditingkatkan atau dirubah. Alasan utama dilakukannya kegiatan evaluasi menurut Kirkpatrick, D., L.\&Kirkpatrick J.,D.(2006) dalam Ramadhon (2016) adalah untuk menentukan tingkat efektifitas dari suatu program pelatihan, sehingga ketika kegiatan evaluasi sudah dilakukan diharapkan dapat menjadi dasar bagi pihak-pihak yang bertanggung jawab dalam 
program tersebut, dalam membuat keputusan berdasarkan hasil evaluasi.

Menurut Siswanto (2003) dalam Dhita dkk), evaluasi dalam kegiatan pendidikan dan pelatihan memiliki tujuan sebagaiberikut:

1) Untuk mengetahui tingkat kemajuan yang telah dicapai oleh peserta pendidikan dan pelatihan dalam suatu periode proses belajar mengajar tertentu.

2) Untuk mengetahui posisi atau kedudukan peserta dalam kelompoknya.

3) Untuk mengetahui tingkat usaha yangtelah dilakukan para peserta dalam kegiatan pendidikan dan pelatihan.

4) Untuk mengetahui efisiensi metode pendidikan dan pelatihan yang digunakan.

Model Kirkpatrick adalah model evaluasi yang dikembangkan pertama kali oleh Donald L. Kirkpatrick dengan menggunakan empat level dalam membuat kategori hasil pelatihan. Empat level tersebut adalah level reaksi (reactions), pembelajaran (learning), perilaku (behavior), dan hasil (results). ModelKirkpatrickini muncul pada tahun 1975 dan masih menjadi model yang paling banyak digunakan untuk melakukan evaluasi atas sebuah pelatihan.

Selanjutnya Keempat tingkatan tersebut dijelaskan sebagai berikut:

1) Reaksi - apa yang dipikirkan dan dirasakan para peserta mengenai kegiatan pelatihan.

2) Pembelajaran - peningkatan pada pengetahuan, keahlian, atau perubahan pada sikap.

3) Perilaku - sejauh mana perubahan pada pekerjaan yang dilakukan peserta sebagai akibat dari kegiatan pelatihan dan kemampuannya untuk melakukan peningkatan dan penerapan.

4) Hasil - dampak pada kegiatan atau lingkungan kerja sebagai akibat dari kinerja peserta pelatihan. Ini merupakan dampak dari pelatihan pada 
organisasi serta klien dari menggunakan empat level dalam peserta pelatihan.

mengkategorikan hasil-hasil

pelatihan. Empat level tersebut

METODE PENELITIAN

1. Jenis Penelitian dan Model perilaku dan hasil.

\section{Evaluasi}

Sesuai dengan tujuan penelitian, jenis penelitian ini dikategorikan sebagai penelitian evaluasi. Penelitian evaluasi merupakan kegiatan penelitian untuk mengumpulkan data, menyajikan informasi yang akurat dan objektif mengenai implementasi program Pendidikan dan Pelatihan yang sudah dilaksanakan (Sudharsono, 1994). Penelitian ini menggunakan metode deskriptif dengan pendekatan kuantitatif dan didukung dengan pendekatan kualitatif. Sedangkan pengumpulan data dengan teknik survei.

Model evaluasi yang digunakan adalah model evaluasi Kirkpatrick merupakan model evaluasi pelatihan yang dikembangkan pertama kali oleh Donald L. Kirkpatrick (1959) dengan

\section{Fokus Penelitian}

Fokus penelitianini adalah melakukan evaluasi level 3 pada model evaluasi Kirkpatrick untuk mengetahui perubahan perilaku purnawidya setelah mengikuti diklat. Penelitian dilakukan untuk mengetahui tingkat penerapan hasil diklat yang menunjukkan kemampuan purnawidya dalam menerapkan materi diklat di tempat tugasnya serta faktor yang mendukung dan menghambat atau menjadi pembatas dalam penerapannya.

\section{Lokasi Penelitian}

Lokasi Penelitian terdiri dari lokasi pengambilan data dan lokasi pengolahan data. Lokasi pengambilan data di Balai Penyuluhan Pertanian tempat bertugas masing-masing purnawidya 
yang menjadi responden. Sedangkan lokasi pengolahan data dan penyusunan laporan penelitian di lakukan di kantor Balai Besar Pelatihan Pertanian Binuang.

\section{Sumber dan Pengumpulan Data}

Penelitian ini menggunakan data primer. Sesuai dengan Peraturan Menteri Pertanian Nomor: 49/Permentan/OT.140/9/2011 tentang pedoman Pendidikan dan Pelatihan Pertanian Aparatur dan Non Aparatur responden evaluasi pasca diklat aparatur pertanian terdiri dari responden utama yaitu purnawidya, dan responden pendukung yaitu atasan langsung purnawidya dan rekan kerja purnawidya. Sedangkan untuk mendukung hasil penelitian diperlukan juga data sekunder berupa dokumen atau laporan yang membuktikan bahwa hasil diklat memang benar telah diterapkan. Metode pengumpulan data dengan metode pengamatan (observasi), wawancara dan pengisian kuesioner. Data yang diperoleh diolah dengan menggunakan persentase.

\section{Instrumen Penelitian}

Untuk menggali data dan informasi dalam penelitian ini menggunakan instrument berupa kuesioner yang telah disiapkan.

\section{PEMBAHASAN}

Hasil penelitian ini menunjukkan tingkat penerapan materi Diklat Manajemen dan Kepemimpinan Balai Penyuluhan Pertanian, Perikanan, dan Kehutanan (BP3K) bagi Pimpinan BP3K untuk 4 (Empat) Mata Diklat yaitu:

Menyusun rencana tahunan BP3K

1) Mengorganisasikan kegiatan BP3K

2) Memfasilitasi pelaksanaan kegiatan penyuluhan diwilayah kerja BP3K

3) Mengendalikan Kegiatan Penyuluhan di wilayah kerja BP3K Penerapan materi Diklat Manajemen dan Kepemimpinan 
BP3K bagi Pimpinan BP3K di Pimpinan BP3K adalah sebesar lapangan berdasarkan keterangan 84,9\% yang termasuk dalam purnawidya, atasan langsung kategori penerapan sangat tinggi. purnawidya, dan mitra/ rekan kerja Ini menunjukkan bahwa purnawidya.

\section{A. Purnawidya}

purnawidya telah menerapkan $84,88 \%$ dari materi yang telah Rata-rata tingkat penerapan dilatihkan. Secara terperinci tingkat materi terhadap 4 (empat) Mata penerapan materi oleh purnawidya untuk tiap-tiap Mata Diklat dapat

Diklat yang telah dilatihkan pada dilihat padaTabel 1 berikut ini:

Diklat Manajemen dan Kepemimpinan BP3K bagi

Tabel 1.

Tingkat Penerapan materi oleh purnawidya untuk setiap Mata Diklat yang dilatihkan

\begin{tabular}{|c|l|c|c|}
\hline No. & \multicolumn{1}{|c|}{ Mata Diklat } & $\begin{array}{c}\text { Tingkat } \\
\text { Penerapan } \\
\text { materi (\%) }\end{array}$ & $\begin{array}{c}\text { Kategori } \\
\text { Tingkat } \\
\text { Penerapan }\end{array}$ \\
\hline 1 & Menyusun Rencana Tahunan BP3K & 85,4 & Sangat Tinggi \\
\hline 2 & $\begin{array}{l}\text { Mengorganisasikan } \\
\text { Kegiatan BP3K }\end{array}$ & 76,9 & Tinggi \\
\hline 3 & $\begin{array}{l}\text { Memfasilitasi pelaksanaan kegiatan } \\
\text { penyuluhan diwilayah kerjaBP3K }\end{array}$ & 88,5 & Sangat Tinggi \\
\hline 4 & $\begin{array}{l}\text { Mengendalikan KegiatanPenyuluhan } \\
\text { di wilayah kerjaBP3K }\end{array}$ & 88,7 & Sangat Tinggi \\
\hline \multicolumn{2}{|c|}{ Rata-rata } & $\mathbf{8 4 , 9}$ & Sangat Tinggi \\
\hline
\end{tabular}

Sumber: BP3K Binuang, 2017

Berdasarkan Tabel 1 dapat tertinggi adalah untuk mata diklat dilihat bahwa tingkat penerapan Memfasilitasi pelaksanaan kegiatan materi secara berurutan dari yang penyuluhan diwilayah kerja BP3K 
sebesar $88,5 \%$, Menyusun rencana tahunan BP3K sebesar 85,4\%, Mengendalikan

Kegiatan

Penyuluhan di wilayah kerjaBP3K sebesar $83,7 \%$ dan yang terendah pada Mata

Diklat

Mengorganisasikan kegiatan BP3K sebesar $76,9 \%$.

Berdasarkan data diatas, diketahui bahwa penerapan materi paling rendah ada pada Mata Diklat Mengorganisasikan Kegiatan BP3K dibandingkan dengan Mata Diklat lainnya yaitu sebesar 76,9\%, walaupun secara kategori tingkat penerapannya sudah termasuk kategori tinggi. Berdasarkan hasil wawancara dengan purnawidya diketahui bahwa menurut sebagian purnawidya kondisi tersebut dipengaruhi oleh pengambilan keputusan terhadap aspek mengorganisasikan kegiatan yang sepenuhnya masih bergantung padakebijakan yang ditentukandi tingkat Kabupaten oleh Badan Pelaksana Penyuluhan Pertanian, Perikanan, dan Kehutanan (BP4K). masing masing seperti pemetaan potensi SDM, dukungan sarana dan prasarana, merancang pemanfaatan potensi SDM, serta merancang pemanfaatan potensi dukungan sarana dan prasarana. Sejauh ini Pimpinan BP3K masih sebatas memberikan masukan dan usulan baik dari aspek SDM Penyuluh ataupun sarana dan prasarana yang diperlukan di BP3K, sedangkan keputusan masih sepenuhnya dipegang dan ditentukan oleh pihak BP4K.

\section{B. Atasan Langsung Purnawidya}

Rata-rata hasil penerapan oleh purnawidya berdasarkan hasil penilaian atasan langsung purnawidya terhadap tingkat penerapan materi untuk 4 (empat) Mata Diklat yang sudah dilatihkan adalah sebesar $85,9 \%$ yang termasuk dalam kategori tingkat penerapan 'SangatTinggi'. Artinya bahwa ratarata tingkat penerapan materi oleh purnawidya menurut atasan langsungnya untuk seluruh Mata Diklat yang telah dipelajari sebesar 
$85,9 \%$. Selengkapnya hasil tingkat penerapan materi oleh purnawidya untuk tiap Mata Diklat dapat dilihat pada Tabel 2 berikut ini.

Tabel 2.

Tingkat Penerapan materi oleh purnawidya untuk setiap Mata Diklat yang dilatihkan menurut penilaian atasan langsung purnawidya

\begin{tabular}{|c|c|c|c|}
\hline No. & Mata Diklat & $\begin{array}{c}\text { Tingkat } \\
\text { Penerapan } \\
\text { materi (\%) }\end{array}$ & $\begin{array}{c}\text { Kategori } \\
\text { Tingkat } \\
\text { Penerapan }\end{array}$ \\
\hline 1 & MenyusunRencanaTahunan BP3K & 90,4 & Sangat Tinggi \\
\hline 2 & $\begin{array}{l}\text { Mengorganisasikan } \\
\text { Kegiatan BP3K }\end{array}$ & 76,1 & Tinggi \\
\hline 3 & $\begin{array}{l}\text { Memfasilitasi pelaksanaan kegiatan } \\
\text { penyuluhan diwilayah kerjaBP3K }\end{array}$ & 89,1 & Sangat Tinggi \\
\hline 4 & $\begin{array}{l}\text { Mengendalikan KegiatanPenyuluhan } \\
\text { di wilayah kerjaBP3K }\end{array}$ & 88,0 & Sangat Tinggi \\
\hline \multicolumn{2}{|r|}{ Rata-rata } & 85,9 & Sangat Tinggi \\
\hline
\end{tabular}

Sumber: BP3K Binuang, 2017

Berdasarkan data diatas, diketahui bahwa penerapan paling rendah menurut penilaian atasan langsung purnawidya ada pada penerapan materi untuk Mata Diklat Mengorganisasikan Kegiatan BP3K dibandingkan dengan Mata Diklat lainnya yaitu sebesar 76,1\%, walaupun kategori penerapannya sudah termasuk tinggi. Dari hasil wawancara dengan atasan langsung purnawidya diketahui bahwa kondisi tersebut dipengaruhi adanya keterbatasan kemampuan di pihak Kabupaten yaitu Badan Pelaksana Penyuluhan Pertanian, Perikanan, dan Kehutanan (BP4K) untuk memenuhi kebutuhan sarana dan prasarana minimal yang dibutuhkan oleh BP3K. Selain itu, keterbatasan jumlah Penyuluh Pertanian Lapangan (PPL) yang ada, mengharuskan sebagian PPL mempunyai wilayah binaan lebih dari 1desa.

Hal ini menimbulkan kesulitan tersendiri dalam hal penempatan dan pengorganisasian sumberdaya 
manusia di BP3K. Paling rendahnya hasil tingkat penerapan materi untuk Mata Diklat Mengorganisasikan Kegiatan BP3K oleh purnawidya menurut penilaian atasan langsung ini sejalan dengan hasil tingkat penerapan materi oleh purnawidya yang juga menmperoleh penilaian paling rendah. Hal ini menunjukkan keterkaitan yang positif antara penilaian yang dilakukan oleh purnawidya dan atasan langsung purnawidya.

\section{Rekan Kerja Purnawidya}

Rata-rata hasilpenerapan oleh purnawidya berdasarkanhasil penilaian rekan kerja purnawidya terhadap tingkat penerapan materi untuk4(empat) MataDiklat yang sudah dilatihkan adalah sebesar $81,9 \%$ yang termasuk dalam kategori tingkat penerapan 'SangatTinggi'. Hal ini menunjukkan bahwa rata-rata tingkat penerapan materi oleh purnawidya menurut rekan kerjanya untuk seluruh Mata Diklat yang telah dipelajari sebesar $81,9 \%$. Selengkapnya hasil tingkat penerapan materi oleh purnawidya untuk tiap Mata Diklat dapat dilihat pada Tabel 3 berikut ini.

Tabel 3.

Tingkat Penerapan materi oleh purnawidya untuk setiap Mata Diklat yang dilatihkan menurut penilaian rekan kerja purnawidya

\begin{tabular}{|c|l|c|c|}
\hline No. & \multicolumn{1}{|c|}{ Mata Diklat } & $\begin{array}{c}\text { Tingkat } \\
\text { Penerapan } \\
\text { materi (\%) }\end{array}$ & $\begin{array}{c}\text { Kategori } \\
\text { Tingkat } \\
\text { Penerapan }\end{array}$ \\
\hline 1 & MenyusunRencanaTahunan BP3K & 86,2 & Sangat Tinggi \\
\hline 2 & $\begin{array}{l}\text { Mengorganisasikan } \\
\text { Kegiatan BP3K }\end{array}$ & 79,8 & Tinggi \\
\hline 3 & $\begin{array}{l}\text { Memfasilitasi pelaksanaan kegiatan } \\
\text { penyuluhan diwilayah kerjaBP3K }\end{array}$ & 84,6 & Sangat Tinggi \\
\hline 4 & $\begin{array}{l}\text { Mengendalikan KegiatanPenyuluhan } \\
\text { di wilayah kerjaBP3K }\end{array}$ & 76,9 & Tinggi \\
\hline \multicolumn{2}{|c|}{ Rata-rata } & $\mathbf{8 1 , 9}$ & Sangat Tinggi \\
\hline
\end{tabular}

Sumber: BP3K Binuang, 2017 
Berdasarkan data di atas, menurut penilaian rekan kerja purnawidya terlihat ada dua Mata Diklat yang hasil tingkat penerapan materinya lebih rendah dari Mata Diklat lainnyakarena masih dalam kategori 'Tinggi', yaitu pada Mata Diklat Mengorganisasikan Kegiatan BP3K $(79,8 \%)$, dan Mengendalikan Kegiatan Penyuluhan di Wilayah Kerja BP3K(76,9\%). Masih belum optimalnya tingkat penerapan materi untuk Mata Diklat Mengorganisasikan Kegiatan BP3K menurut sebagian rekan kerja purnawidya dipengaruhi oleh Pimpinan BP3K yang tidak berwenang dalam pemetaan dan pemanfaatan potensi SDM serta sarana dan prasarana. Pimpinan BP3K hanya bersifat memberikan masukan dan usulan kepada pihak BP4K, sedangkan keputusan sepenuhnya ada di BP4K. Sedangkan untuk Mata Diklat Mengendalikan Kegiatan Penyuluhan di wilayah kerja BP3K belum optimal karena pada saat pengambilan data, ada beberapa rangkaian kegiatan penyuluhan belum dilaksanakan namun sudah direncanakan. Diantara kegiatan yang belum dilaksanakan adalah Mengevaluasi Pelaksanaan dan Dampak serta Laporan Kegiatan yang memang belum saatnya dilaksanakan pada saat pengambilan data dilakukan.

\section{KESIMPULAN}

1. Tingkat penerapan materi pada Diklat Manajemen dan Kepemimpinan BP3K bagi Pimpinan BP3K diketahui sangat tinggi dengan persen penerapan purnawidya terhadap materi diklat sebesar $84,9 \%$ yang termasuk kedalam kategori penerapan sangat tinggi, berdasarkan hasil penilaian dari atasan langsung purnawidya menunjukan tingkat penerapan sebesar 85,9\% dengan kategori penerapan sangat tinggi, dan penilaian rekan/mitra kerja 
purnawidya menunjukan tingkat penerapan sebesar $81,9 \%$ dengan kategori sangat tinggi.

2. Tingkat penerapan materi tertinggi menurut punawidya yaitu pada Mata Diklat Memfasilitasi Kegiatan

Penyuluhan di wilayah kerja BP3K sebesar 88,5\% dengan kategori penerapan sangat tinggi, sedangkan menurut atasan langsung dan rekan kerja penerapan tertinggi ada pada Mata Diklat Menyusun Rencana Tahunan BP3K dengan masingmasing $90,4 \%$ dan $86,2 \%$ dengan kategori penerapan sangat tinggi.

3. Tingkat penerapan materi terendah menurut purnawidya, atasan langsung, dan mitra kerja ada pada Mata Diklat Mengorganisasikan Kegiatan BP3K dengan persentase penerapan masing-masing $76,9 \%$, $76,1 \%$, dan $79,8 \%$. Walaupun demikian, tingkat penerapan materi ini masih termasuk dalam kategori penerapan tinggi.

\section{SARAN}

Hasil penelitian evaluasi ini sebagai umpan balik bagi Balai Besar Pelatihan Pertanian Binuang, walaupun secara keseluruhan tingkat penerapan materi tergolong tinggi, namun sebaiknya bagi setiap diklat yang akan dilakukan Evaluasi Pasca Diklat perlu dilakukan bimbingan lanjutan terlebih dahulu, sehingga hal-hal yang menjadi pembatas purnawidya untuk dapat menerapkan materi hasil diklat dapat diantisipasi dan diupayakan pemecahannya dari awal. Untuk lebih berdaya guna pada saat bimbingan lanjutan perlu menghadirkan pihak terkait dan berwenang di tingkat kabupaten khususnya yang menangani penyuluhan, agar dukungan terhadap apa yang diperlukan oleh purnawidya diklat dapat difasilitasi. 


\section{DAFTAR PUSTAKA}

Undang Undang Nomor 101 Tahun 2000 Tentang Pendidikan dan Pelatihan Jabatan Pegawai Negeri Sipil.

Undang Undang Republik Indonesia No. 16 Tahun 2006 Tentang Sistem Penyuluhan Pertanian, Perikanan, dan Kehutanan.

Peraturan Menteri Pertanian Nomor: 49/Permentan/OT.140/9/2011

Tentang Pedoman Pendidikan dan Pelatihan Pertanian Aparatur dan Non Aparatur.

Peraturan Menteri Pertanian Nomor 26/Permentan/OT.140/4/2012 Tentang Pedoman Pengelolaan Balai Penyuluhan.

Peraturan Menteri Pertanian Nomor 104/Permentan/OT.140/10/2013 Tentang Organisasi dan Tata Kerja Balai Besar Pelatihan Pertanian Binuang.
H. Hadari Nawawi. 2005. Metode Penelitian Bidang Sosial. Gadjah Mada University Press.

Dhita Ayu Meitaningrum, Imam Hardjanto, Siswidiyanto.. Efektivitas Pendidikan dan Pelatihan dalam Meningkatkan Kinerja Pegawai (Studi pada Badan Kepegawaian Daerah Kabupaten Malang). Jurnal Administrasi Publik (JAP), Vol1, No.3. 2013.

Syafril Ramadhon. Forum Diklat Vol.06 No.1. 2016. Penerapan Model Empat Level Kirk Patrick Dalam Evaluasi Program Pendidikan Dan Pelatihan Aparatur Di Pusdiklat Migas.

http://evaluasipendidikan.blogspot.c o.id/2008/03/evaluasi-programsebuah pengantar. html. diakses tanggal 6 Pebruari 2017. 